\title{
Front Matter: Volume 10908
}

, "Front Matter: Volume 10908," Proc. SPIE 10908, Frontiers in Ultrafast Optics: Biomedical, Scientific, and Industrial Applications XIX, 1090801 (22 May 2019); doi: 10.1117/12.2531477

SPIE. Event: SPIE LASE, 2019, San Francisco, California, United States 


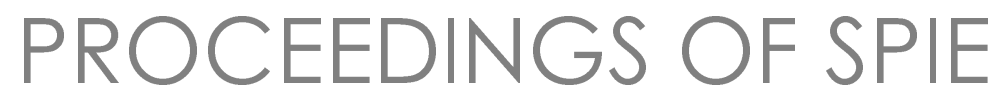

\title{
Frontiers in Ultrafast Optics: Biomedical, Scientific, and Industrial Applications XIX
}

\author{
Peter R. Herman \\ Michel Meunier \\ Roberto Osellame \\ Editors
}

2-5 February 2019

San Francisco, California, United States

Sponsored by

SPIE

Cosponsored by

Amplitude (France)

TRUMPF Inc. (United States)

Published by

SPIE 
The papers in this volume were part of the technical conference cited on the cover and title page. Papers were selected and subject to review by the editors and conference program committee. Some conference presentations may not be available for publication. Additional papers and presentation recordings may be available online in the SPIE Digital Library at SPIEDigitalLibrary.org.

The papers reflect the work and thoughts of the authors and are published herein as submitted. The publisher is not responsible for the validity of the information or for any outcomes resulting from reliance thereon.

Please use the following format to cite material from these proceedings:

Author(s), "Title of Paper," in Frontiers in Ultrafast Optics: Biomedical, Scientific, and Industrial Applications XIX, edited by Peter R. Herman, Michel Meunier, Roberto Osellame, Proceedings of SPIE Vol. 10908 (SPIE, Bellingham, WA, 2019) Seven-digit Article CID Number.

ISSN: 0277-786X

ISSN: 1996-756X (electronic)

ISBN: 9781510624580

ISBN: 9781510624597 (electronic)

Published by

SPIE

P.O. Box 10, Bellingham, Washington 98227-0010 USA

Telephone +1360 676 3290 (Pacific Time) · Fax +1 3606471445

SPIE.org

Copyright @ 2019, Society of Photo-Optical Instrumentation Engineers.

Copying of material in this book for internal or personal use, or for the internal or personal use of specific clients, beyond the fair use provisions granted by the U.S. Copyright Law is authorized by SPIE subject to payment of copying fees. The Transactional Reporting Service base fee for this volume is $\$ 18.00$ per article (or portion thereof), which should be paid directly to the Copyright Clearance Center (CCC), 222 Rosewood Drive, Danvers, MA 01923. Payment may also be made electronically through CCC Online at copyright.com. Other copying for republication, resale, advertising or promotion, or any form of systematic or multiple reproduction of any material in this book is prohibited except with permission in writing from the publisher. The CCC fee code is 0277$786 \times / 19 / \$ 18.00$.

Printed in the United States of America by Curran Associates, Inc., under license from SPIE.

Publication of record for individual papers is online in the SPIE Digital Library.

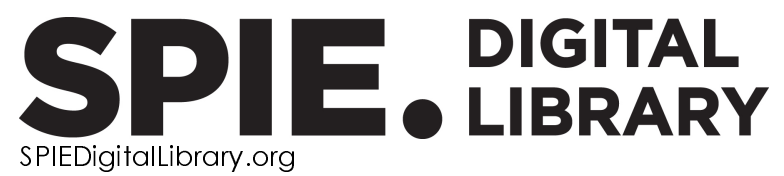

Paper Numbering: Proceedings of SPIE follow an e-First publication model. A unique citation identifier (CID) number is assigned to each article at the time of publication. Utilization of CIDs allows articles to be fully citable as soon as they are published online, and connects the same identifier to all online and print versions of the publication. SPIE uses a seven-digit CID article numbering system structured as follows:

- The first five digits correspond to the SPIE volume number.

- The last two digits indicate publication order within the volume using a Base 36 numbering system employing both numerals and letters. These two-number sets start with $00,01,02,03,04$, 05, 06, 07, 08, 09, OA, OB ... 0Z, followed by 10-1Z, 20-2Z, etc. The CID Number appears on each page of the manuscript. 


\section{Contents}

$\checkmark \quad$ Authors

vii Conference Committee

ULTRAFAST LASER-MATTER INTERACTION

$1090802 \quad X$-ray emission during ultrashort pulse laser processing (Invited Paper) [10908-1]

1090803 Weyl semimetals in circularly-polarized ultrafast laser field [10908-2]

1090804 Femtosecond laser-based formation of electrically conductive silicon carbide on PDMS [10908-3]

BIOMEDICAL APPLICATIONS OF ULTRAFAST LASERS

10908 OA Application of laser surface nanotexturing for the reduction of peri-implantitis on biomedical grade 5 Ti-6Al-4V dental abutments [10908-9]

3D STRUCTURING OF TRANSPARENT MATERIALS

10908 OB High-resolution femtosecond laser 3D micromachining using low-NA focusing systems (Invited Paper) [10908-10]

ADVANCED ULTRAFAST LASERS AND BEAM CONTROLS

$10908 \mathrm{~J} \quad$ Complete temporal measurement of ultrashort laser pulses using interferometric GRENOUILLE [10908-18]

\section{FS-LASER-BASED INTEGRATED OPTICAL DEVICES}

$109080 \mathrm{M}$ Switchable dual wavelength picosecond fiber laser source operating around $780 \mathrm{~nm}$ for advanced Raman spectroscopy [10908-21]

$10908 \mathrm{ON} \quad$ Next generation of tailored mode selective transmission gratings for fiber integrated devices [10908-23]

$1090800 \quad$ Tuning multichannel filters based on FBG in multicore fibers [10908-24] 
ULTRAFAST LASER MICRO/NANOMACHINING

10908 OU Characterization of surface plasmons inducing nanoablation on nonmetallic materials excited with intense femtosecond laser pulses (Invited Paper) [10908-30]

POSTER SESSION

109081 A W-type co-axial chalcogenide optical fiber for coherent mid-IR supercontinuum generation [10908-22] 


\section{Authors}

Numbers in the index correspond to the last two digits of the seven-digit citation identifier (CID) article numbering system used in Proceedings of SPIE. The first five digits reflect the volume number. Base 36 numbering is employed for the last two digits and indicates the order of articles within the volume. Numbers start with 00, 01, 02, 03, 04, 05, 06, 07, 08, 09, OA, OB...0Z, followed by 10-12, 20-2Z, etc.

Apalkov, Vadym, 03

Bonse, Jörn, 02

Cheng, Ya, OB

Chu, Wei, $O B$

Cunha, Alexandre, $\mathrm{OA}$

Dortu, Fabian, OM

Goebel, Thorsten A., 0N, $0 \mathrm{O}$

Hagiya, Masato, OU

Hayashi, Shuichiro, 04

Heck, Maximilian, ON, $0 \mathrm{O}$

Hernandez, Yves, OM

Hesse, Bernard, OA

Huth-Herms, Katrin, OA

Jones, Travis, 0J

Katayama, Akito, 04

Kieburg, Heinz, OA

Krämer, Ria G., ON, $0 O$

Krüger, Jörg, 02

Lecourt, Jean-Bernard, OM

Legall, Herbert, 02

$\mathrm{Li}$, Wenbo, OB

Luo, Xing, 1A

Matzdorf, Christian, ON

Miyaji, Godai, OU

Moriyama, Daiki, oU

Nakajima, Yasutaka, 04

Nedyalkov, Nikolay N., 04

Nematollahi, Fatemeh, 03

Nguyen, Hoa Phuoc Trung, $1 \mathrm{~A}$

Nolte, Stefan, ON, 00

Ohishi, Yasutake, 1A

Ouinten, Chems-Eddine, OM

Petkovšek, Rok, OJ

Polte, Julian, OA

Qiao, Lingling, OB

Richter, Daniel, ON, $0 \mathrm{O}$

Saini, Than Singh, 1A

Schwanke, Christoph, 02

Schwartz, Georg, ON

Schweitzer, Luiz, OA

Siems, Malte P., ON

Stockman, Mark I., 03

Šušnjar, Peter, OJ

Suzuki, Takenobu, 1 A

Tan, Yuanxin, OB

Terakawa, Mitsuhiro, 04

Tong, Tong Hoang, 1A

Trebino, Rick, OJ

Tünnermann, Andreas, ON
Uhlmann, Eckart, OA

Wang, Peng, OB

Weißflog, M., $0 O$ 
Proc. of SPIE Vol. 10908 1090801-6

Downloaded From: https://www.spiedigitallibrary.org/conference-proceedings-of-spie on 26 Apr 2023 Terms of Use: https://www.spiedigitallibrary.org/terms-of-use 


\section{Conference Committee}

Symposium Chairs

Beat Neuenschwander, Berner Fachhochschule Technik und Informatik (Switzerland)

Xianfan Xu, Purdue University (United States)

Symposium Co-chairs

Koji Sugioka, RIKEN Center for Advanced Photonics (Japan)

Reinhart Poprawe, Fraunhofer-Institut für Lasertechnik (Germany)

Program Track Chairs

Henry Helvajian, The Aerospace Corporation (United States)

Guido Hennig, Daetwyler Graphics AG (Switzerland)

Conference Chairs

Peter R. Herman, University of Toronto (Canada)

Michel Meunier, Ecole Polytechnique de Montréal (Canada)

Roberto Osellame, CNR- Istituto di Fotonica e Nanotecnologie (Italy)

Conference Program Committee

Craig B. Arnold, Princeton University (United States)

Yves Bellouard, Ecole Polytechnique Fédérale de Lausanne (Switzerland)

Adela Ben-Yakar, The University of Texas at Austin (United States)

Alexander Heisterkamp, Leibniz Universität Hannover (Germany)

Denise M. Krol, University of California, Davis (United States)

Eric Mazur, Harvard University (United States)

Eric P. Mottay, Amplitude Systèmes (France)

Beat Neuenschwander, Berner Fachhochschule Technik und Informatik (Switzerland)

Stefan Nolte, Friedrich-Schiller-Universität Jena (Germany)

Aleks Ovsianikov, Technische Universität Wien (Austria)

Christopher B. Schaffer, Cornell University (United States)

Jan Siegel, Instituto de Optica "Daza de Valdés" (Spain)

Koji Sugioka, RIKEN Center for Advanced Photonics (Japan)

Mitsuhiro Terakawa, Keio University (Japan)

Alfred Vogel, Universität zu Lübeck (Germany)

Sascha Weiler, TRUMPF Inc. (United States)

Dvir Yelin, Technion-Israel Institute of Technology (Israel) 


\section{Session Chairs}

1 Ultrafast Laser-Matter Interaction

Michel Meunier, Ecole Polytechnique de Montréal (Canada)

2 Biomedical Applications of Ultrafast Lasers

Michel Meunier, Ecole Polytechnique de Montréal (Canada)

3 3D Structuring of Transparent Materials

Peter R. Herman, University of Toronto (Canada)

4 Advanced Ultrafast Lasers and Beam Controls

Peter R. Herman, University of Toronto (Canada)

5 fs-Laser-based Integrated Optical Devices

Roberto Osellame, CNR- Istituto di Fotonica e Nanotecnologie (Italy)

$6 \quad$ Ultrafast Laser Writing of Optical Waveguides

Roberto Osellame, CNR- Istituto di Fotonica e Nanotecnologie (Italy)

$7 \quad$ Ultrafast Laser Micro/Nanomachining

Stefan Nolte, Friedrich-Schiller-Universität Jena (Germany)

8 High-order Harmonic Generation

Ya Cheng, Shanghai Institute of Optics and Fine Mechanics (China) 